\title{
Cross- and trans-language morphology The lexicography of Indonesian names
}

\author{
DICK VAN DER MEIJ
}

\begin{abstract}
Different form many other name-giving possibilities in the world, in Indonesia parents are free to give their children any name they like. These names, many of which are auspicious in view of the child's future, are often constructed by means of productive morphological procedures. Seven suffixes are followed through history and culture and their possibilities in making new names are explored. The suffixes concern the female -ingsih, -ingrum, -ingtyas, -ingdyah, -astuti, -wati, and the male-wan. Various ins and outs concerning these suffixes are explored and their attachments to various words from various word classes from Indonesian, Javanese and other language revealed. Cross-language name construction leads to trans-language creations that play a possible role in the constitution of Indonesian nation building. The procedures moreover seem to indicate trends away from the inclination to give children Muslim names.

KEYWORDS

Indonesian language, Javanese language, morphology, lexicography, Indonesian name giving, personal names, Javanese royal history, Javanese culture.
\end{abstract}

'As expected, the women's 5,000-meter specialist Triyaningsih and discus thrower Dwi Ratnawati successfully defended their domination of the Main Stadium of the National Sports Complex in Vientiane on Monday' (The Jakarta Post 15 December 2009, p. 24).

\subsection{INTRODUCTION}

In the world of Indonesian linguistics, surprisingly little research has been devoted to personal names. The only one that springs to mind is E.M. Uhlenbeck's 1969 article in Word. ${ }^{1}$ He introduces us to the morphological

1 E.M. Uhlenbeck, 'Semantic features of Javanese personal names', Linguistic studies

DICK VAN DER MEIJ defended his thesis: Puspakrema: A Javanese Romance from Lombok in 2002 at Leiden University. He has worked for Nuffic and Leiden University and has edited and translated numerous works from Indonesian to Dutch and English and vice versa. He is at present affiliated with the Center for the Study of Religion and Culture and of the Center for the Study of Islam and Society of the Syarif Hidayatullah Islamic State University in Jakarta. Dick van der Meij may be contacted at: dickvdm2005@yahoo.com.

(c) 2010 Faculty of Humanities, University of Indonesia 
principles underlying many contemporary Javanese names but whether or not new names can be constructed based on the principles he elucidates remains in the dark.

As an important part of the daily lexicon of language users, it is remarkable that little research is carried out into this particular field of the language's lexicography. This is the more surprising as the number of personal and other names people use on a daily basis is staggering. The study of personal names is moreover important as it reveals much of the linguistic competence of the language's speakers in combining lexical elements, in this case from various languages. It also reveals the ease with which speakers are able to transcend language barriers; it would indeed seem that in Indonesia these barriers are malleable and that 'language osmosis' is by no means something frowned upon.

The quote from The Jakarta Post above mentions two female names, Triyaningsih and Ratnawati that have been made though the application of productive name-making procedures. The first name ends in the productive suffix -ningsih, and the second ends in -wati. The procedures are so productive that it would seem that almost every day new names are made and collecting them is an unending enterprise. ${ }^{2}$

This article discusses the ways names are created from elements across languages and turned into names that transcend the languages of the compound elements. ${ }^{3}$ I will pay attention to seven productive systems of name making, six female and one male. The names discussed here all end in a specific suffix: female suffixes -ningsih, -ningrum, -ningtyas, -ningdyah, -astuti, and $-w a t i$ and the male suffix -wan. The suffixes discussed here are only used in the name making procedures discussed below and they are not applied in any other part of the Indonesian or Javanese languages. Interestingly, there seem to be many more productive procedures at work in name giving for girls than for boys. -Wan is almost as productive as -wati, but other male suffixes such as - man are used far less often than any of the suffixes addressed here.I have chosen these names because they give a good impression of name-building practices in Indonesia, and also because they reveal an interesting trend that is 180 degrees in opposition to the perceived tendency in this predominantly Muslim country to give children Islamic or Islamic-inspired names, a fashion that has become especially general under the last generation of Muslims. At first glance, these names therefore seem to escape the ongoing Islamization of the country but there is some reason for caution. The names discussed here may be the only name a person carries, but usually a person carries more than one name and the names provided and discussed below are only those that have

presented to André Martinet, Word 25/3: 321-335. Reprinted in Uhlenbeck 1978 and translated into Indonesian in Uhlenbeck 1982.

2 For this article, no attempt has been made to see when the names were constructed. Apart from the historical overview of the origins of the suffixes used, the emphasis of this article remains largely morphological and ignores issues of synchronicity and diachronicity.

3 That these highly productive ways of names' construction have escaped the attention of linguists is a puzzle to me. 
been made based on the productive procedures discussed in this article and the other names people carry may indeed reveal an Islamic or other religious background. The article limits itself to the names under discussion and any other names individuals may carry have not been included. However, in some individual cases these names are shown to explain certain points pertinent to the discussion. Islamic and other religious affiliations may be constituent parts of the names that use the suffixes discussed here, for instance in the ubiquitous name Rachmawati and all its variant spellings and the sample used here even includes the name Muslimawati. They are exceptions rather than the rule. Below some examples of names that carry a religious affiliation are mentioned.

\subsection{NAMES IN INDONESIA}

Names in Indonesia are often made using productive systems of name formation, something that is rare in other parts of the world. This is not to indicate that this productiveness is a phenomenon that is found among all the ethnic groups in this ethnicity-rich archipelago. It may be that in the use of the names discussed here we are indeed talking about a Javanesebased system that has escaped its ethnic confines and roams throughout the entire archipelago - as indeed the Javanese people have through the many transmigration projects executed in the country in the past; the system has reached adjacent Bali for sure, and Lombok as well.

Many Javanese carry only one name, for instance, Soekarno and Soeharto, two of Indonesia's Presidents and many people in Indonesia do not carry a family name but only carry given names, which makes it difficult to find out who a person really is as regards to their parents and other family connections.

Seldom is a name given which does not in one way or another convey a kind of message, or a kind of hope or expectation for the newborn child. In a way, a child's name is the shortest and most persistent mantra its parents utters over it in order to help it through life. A name may reflect the circumstances when a child was born or how it entered the world. It may, for instance reflect that the process of delivery was smooth or laborious. If the 'mantra' fails and the child often becomes ill or is otherwise unsuccessful in life, its name is often changed for another in the hope to reverse unhappy conditions.

Interestingly, patronymics are infrequently used in modern Indonesia. The only instances I found include the names of former Indonesian President, Megawati Soekarnoputri (Megawati, Soekarno's daughter), and her brother Guntur Soekarnoputra (Guntur, Soekarno's son) and their brother Guruh Soekarnoputra and sisters Rachmawati and Sukmawati Soekarnoputri.

We have so far been talking about an individual's 'official' name or names, but that may not be the name or names the person uses or is known under. Many people carry names in daily life that do not, or only distantly, refer to their own name or are abbreviations of their name. Of course nicknames are widely used as well. 
As implied above, Muslim names have entered this predominantly Muslim country and, of late, it is increasingly difficult to establish a person's ethnic background due to the Islamic names people carry, which are ethnic free. Also here highly productive procedures are at work. For instance, the use of male names with the Muslim ending -uddin or -udin seems to become greater and greater, for instance, Akhimuddin, Amiruddin, Badaruddin, Baharuddin, Burhahuddin, Hasanuddin, Imaduddin, Jaenuddin, Jamaluddin, Komaruddin, Nasaruddin, Nuruddin, Risuddin, Sahabuddin, Samaruddin, Syamsuddin, Tawalinuddin, Tajuddin, Wahiduddin, Zainuddin, Badarudin, Baharudin, Haerudin, Hanifudin, Izzudin, Jalaludin, Kasrudin, Nurudin, Saifudien, Salahudin, Sihabudin, and many such. ${ }^{4}$

Names may also be given in commemoration of a religious occasion at the time of the new baby's birth. For instance, many people are called Fitri, Ramadan or Ramdhoni (abbreviated to Dhoni) because they were born in the fasting month of Ramadan or around Id 'ul Fitri, the festive end of that month. The same holds for people carrying the name Puasaningrum, Puasaningdyah and Puasawati who were likely born in the fasting month. I once met a taxi driver whose name was Isra Miraj because he was apparently born on the 27th of the month Rajab, the date of the ascension to heaven (Isra Miraj) of the Prophet Muhammad (see The Photograph). Also in Christianity, the name may reflect a religious festivity such as evidenced by the name Natalwati to commemorate Christmas, and Paskahwati and Paskahningrum in commemoration of Easter. Children also often get a name pointing to the time they were born such as the month or the early morning, or names that point to the weather conditions surrounding the delivery. ${ }^{5}$ An individual's place among their siblings is often

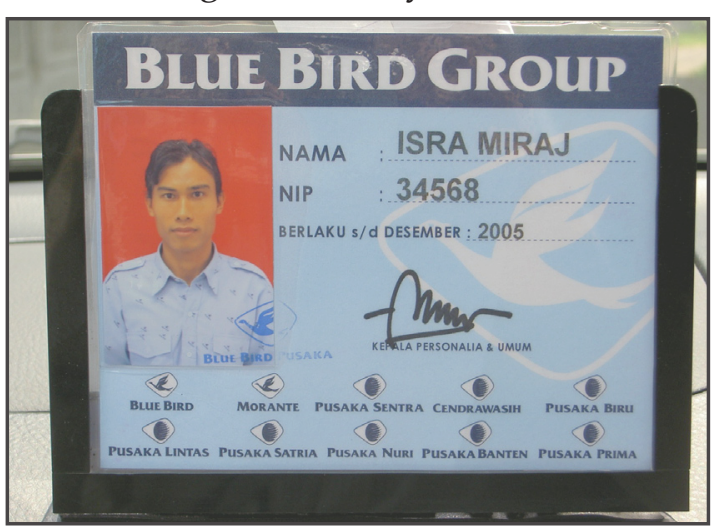

Photograph by the author, 2005 . indicated by a numeral indicating whether they are the first, second etcetera child. ${ }^{6}$

Over time, fashion and modernity has also contributed to names and the countless Ciskas, Bettys, Rudys, Ellys, Anitas, Lolitas, and Iwans and many more other Western names are given to this day. People moreover often carry names combining Western and Indonesian names, or Arabic,

$4 \quad$ It would be incorrect to think that these names are exclusively Indonesian. Many are also found in other places of the Muslim world but I have the impression that some are Indonesian-made. More research on this is needed, however.

5 For instance, Januarita, Januarisman, Febri, Febriyadi, Febrina, Febriansah, Febriami, Febriandirza, Febriana, Febrianti, Febriyanti, Febrifianyi, Febrianto, Apriadi, Apriliani, Aprilianti, Yuliantino, Meiwati, Meiwita, Juni, Juniartini, Juniartha, Juniati, Juniarsi, Junita, Juniawan, Yuniyanti, Yuli, Yulianti, Juliastri, Julnaidi, Agustiani, Auguste, Agustina, Agustini, Agustiawan, Fajar (early morning), Halilintar (lightning), Ratri (evening), and so forth and so on.

6 Eka, Eko (one), Dwi (two), Tri (three), etcetera. 
or Christian names combined with names indicative of one's ethnic background, rank among siblings and conditions or time of birth.

In short, the variation is overwhelming and names are sometimes created rather unexpectedly. Eldowan Arief explained to me that his name was made up of $E$, because he was the fifth child in the family, $l$ for lahir (born), $\mathrm{d}$ for di- (passive prefix), o for operasi (surgery) +- wan because he is a boy. Arief was the doctor who delivered him. Fetri Aswanti was thus called as she was born in February $(\mathrm{Fe})$ as the third child (tri), the daughter of Suhailah (anak Suhailah, As) and to indicate that she is an Eastern lady (wanita timur, wanti). ${ }^{7}$ One parent was so charmed by Martina Navratilova that he named his daugther Lativa Sovianavratilova. An extreme example of a Muslim inspired name is Fatwa Mui which means a fatwa (Islamic legal decision) made by the MUI, Majelis Ulama Indonesia (Indonesian Ulama Council). A last example is one whose meaning I would never have guessed from the name only. A Balinese father gave his daughter the name Faradynawati out of admiration for Michael Faraday, the inventor of the Faraday cage! ${ }^{8}$

\subsection{NAMES AND ETHNICITY AND NATIONALITY}

Indonesia is an amalgam of large numbers of ethnic and social groups and below I will briefly introduce some aspects of Indonesian 'traditional', ethnicity-related names. These names are often indications of a person's ethnic background, whether they still live in their ethnic place of origin or not. If we start in North Sumatra, people whose name sounds like Sihombing, Simatupang, Situmorang, Siagian, Siringoringo, etcetera. originate from Batak ethnic groups. People more knowledgeable in Batak ethnic elements will undoubtedly see much more in these names and will probably be able to tell from what subethnic stratum a person originates. Names like Pattimura, Litamahuputty, Lumatalale, Manusama, Pattipilohy, etcetera come from the Moluccas; Lumenta, Maukur, Mawuntu, Pinontoan, and Wowor hail from Manado and surroundings in North Sulawesi (Yapi Tambayong 2007). ${ }^{9}$ Natanegara, and Kusumaatmaja, etcetera come from West Java while Notonegoro, and Kusumoatmojo stem from Central Java. Many Javanese have names starting with the prefix Su- ('good'), we need only think of Soekarno (Sukarno) and Soeharto (Suharto) who have already been mentioned above. Productive names in Javanese aristocratic circles are almost invariably compounds of various meaningful particles, each name indicative of one's rank and position in the palace. People named Nanang, Usep, Asep, Cecep, Rikrik, Aang and such are West Javanese (Sundanese) men and people whose names start with Wayan (first-born, also Putu), Made (second-born, also Nengah and Kadek), Nyoman (third-born, also Komang), and fourth-born Ketut come from Bali where the preceding I denotes a male and $\mathrm{Ni}$ a female. In Bali, a person's place and caste is immediately visible from

\footnotetext{
-wanti is also becoming a productive suffix in female name making.

Personal information from the people concerned.

This is one of the rare examples of a dictionary of a regional language that includes many personal names and explains them.
} 
their name and no mistakes are possible on this front.

Incidentally, in many cultures it is taboo to refer to a person's personal name, or even to know it. In Bali, for instance, people often refer to one another simply by the indication of their place among their siblings. There are thus thousands and thousands of Wayan's and Ketut's who are only known under that name and people have no clue as to what their complete names might be.

In the old days, in Java, it was easy to see from what social circles a person hailed. In short, his/her name gave him/her away. Uhlenbeck gives some nice examples of the morphological rules underlying the differences between names from different strata in society. Often a mere change in vowel suffices to distinguish a name from high to low class (Sětradikara [low] and Sastradikara [higher], Singasĕmita [low] and Singasasmita [higher], Uhlenbeck 1982: 382). Abbreviated names also usually indicate a lower social position compared to a person carrying the unabbreviated one: Camuka (low) but Secamuka (higher), Jadipa (low) but Jayadipa (higher) etceteraetra (Uhlenbeck 1982: 382).

In some areas names are not just invented by the parents and given at birth, but are only provided during rituals after the most propitious name for the child has been agreed upon. In Bali, for instance, names are given after rituals and are chosen by a Priest, rather than by the parents (see Hinzler 1988). ${ }^{10}$ Usually, rituals and practices that surround name-giving and information on the names in use may be found in anthropological treatises on ethnic groups in the archipelago. Usually they are found in ethnic descriptions, for instance, in S. Hylkema o.f.m.'s treatise on the Nalum, a group of Papua in the Star Mountains of Papua. He provides an interesting discussion about the kind of names children get, when they get their names, and what the names convey (see Hylkema 1974: 171-176). Another example is J.P.K. van Eechoud's Etnografie van de Kaowerawédj of Central Papua. He also pays attention to the moment a child obtains its name and the circumstances surrounding the birth of the child. Similar to many places in Indonesia, for instance also mentioned in Hylkema's work, the circumstances of birth are of such importance that they are memorized by the name of the child (see Eechoud 1962: 41-44).

The importance of names in emotional nation building in Indonesia has been overlooked. This is a pity as it may teach us a lot about the extent to which the people consider themselves members of the Unitary Indonesian Republic or rather of the ethnic group they were born into. The fact that names and the linguistic procedures how to create them have not drawn the attention of social scientists is thus a pity because they give a clear example of how nation building on the individual level may work and develop. Consider, for instance, the following names in our sample created the basis of the proper name of a national hero or president as mentioned above: 
Hatta $^{11}$ (Hattaningsih, Hattaningrum), Rasuna ${ }^{12}$ (Rasunawati), Soekarno ${ }^{13}$ (Soekarnoningsih, Soekarnowati), and Kartini ${ }^{14}$ (Kartininingsih, Kartininingrum, Kartininingdyah, Kartiniwati, Kartiniwan). Interesting in this light are also the names Merdekaningsih, Merdekaningrum, Merdekaningtyas, Merdekawati, and Merdekawan, all created with the word merdeka 'independence'. ${ }^{15}$

\subsection{GATHERING AND GROUPING NAMES}

For this research, a good sample of names is, of course, a prerequisite. Since I consider this article a pioneer study, I have not turned the exact method of the compilation of this sample into a problem yet. I collected as many names as I could and I have about 7000 names. The search consisted of randomly found names in newspapers and other periodicals, names of friends and colleagues, and lists of names put up in the supermarket containing names of winners of prizes, and on banners on the street. In addition, lists of names of students accepted at their schools as found in newspapers were browsed. Names of friends' friends I found in Facebook were also a great help. Once a name was found carrying one of the suffixes discussed here, I googled the first part of the name combined with the other suffixes to see if they were in use. So, when I found Kusumaningsih, I googled the names Kusumaningrum, Kusumaningtyas, Kusumaningdyah, Kusumastuti, Kusumawati and Kusumawan to see if they existed. Of course this is not a 100 per cent full proof that names do not exist, but when they were found through Google, their validity was established. It is for this reason that no definite statements will be made about frequency and popularity of names.

In order to define patterns in the name-giving processes, some of which are presented below, I first grouped the names based on the suffix they used. Subsequently, they were divided based on the word classes of the first part of the names and on semantic characteristics, which will follow below. Many

11 Muhammad Hatta (1902-1980) jointly proclaimed Indonesian Independence on 17 August 1945 with Soekarno, and was the first Vice-President of Indonesia under President Soekarno.

12 Hj. Rangkayo Rasuna Said (1910-1965) was a fighter for women rights and she is an Indonesian National Hero. She was the first female minister in a cabinet under President Soekarno.

13 Soekarno proclaimed Indonesian Independence on 17 August 1945 with Muhammad Hatta and was the first President of Indonesia.

${ }_{14}$ Raden Ajeng Kartini (1879-1904) is considered the first Javanese woman to entertain feminist ideas.

15 Research on names, their spread over the archipelago, and the name-giving procedures that transgress ethnic and linguistic borders may be an interesting way to look at nation building. When a name moves let us say from Java to Bali and beyond and is being adopted by people from other ethnic backgrounds, may be understood in the sense that the Javanese background of the name loses its significance in favour of a shared Indonesian background. That names can be a sensitive issue in Indonesia became apparent when during Soeharto's Old Order regime Chinese Indonesians were more or less forced to relinquish their Chinese names in favour of indigenous - usually Javanese, or rather, Javanese sounding - ones. The fact that nowadays there is an overwhelming preference for Arabic names should probably also be seen in the light of the direction this country is going. 
of the meanings of the names in the sample are clear enough, but because many names are also made on the basis of abbreviations of names of mothers and fathers and what not, it is not possible to understand them all. In order to decipher the meanings of all the names, extensive fieldwork would be required.

After the presentation of some linguistic aspects of the names, some historical and cultural background follows to put the names in a wider perspective. It will become obvious from what is said below that we are talking about a Javanese ethnic background of these names. We will see that in the more distant past (as far as I was able to establish) there was a substantial less number of names based on the suffixes in use compared to the overwhelming number of names given at present or in the recent past.

\section{MORPHOLOGICAL ASPECTS}

\subsection{GeNERAL OBSERVATIONS}

With the exception of $w a n^{*}$ the suffixes under discussion are also found as proper names in their own rights. Wati is the most well known but names like Ningsih, Ningrum, Ningtyas, Ningdyah, and Astuti are often encountered as well. $W_{a n}^{*}$ was never found as a name and is only used as an abbreviated form of a larger name carrying the -wan suffix. We should also mention that names spelled as one word may be encountered spelled as two separate words and should thus in reality be considered two names. Thus we find Kusumaningrum but also Kusuma Ningrum etcetera. Combinations that are found as two words do not necessarily also feature as one word or the other way around.

Combinations of the suffixes leading to proper names have also been encountered, for instance, Astutiningsih, Astutiningrum and Astutiningtyas, Watiningsih, Watiningrum, and Watiningdyah, Ningtiyaswati and Ningtiyaswan. Sometimes two suffixes combine with a preceding particle such as Amborowati-ningsih. Occasionally the same or almost the same particle is repeated like in Watiwati or Arumningrum, leading to alliteration.

If we look at the names before and/or coming after the names with the suffixes under discussion we sometimes encounter nice examples of rhyming names and names made up using different suffixes resulting in something special. For instance, Maria Riastuti Ryaningrum, Tuti Ningsih Purbaningrum, Triningtyasasih Bawaningrum, Berlianingsih Kusumawati, Sarityastuti Santi Saraswati, Sudarmawan Darmawan, Astuti Giriningsih, Dhian Sistemardika Ningdiah, etcetera.

\subsection{1 - WATI AND - WAN}

Suffixes -wati and -wan are simply added to the stem without any changes to the stem or to the suffix. A note should be made here that some words in the Indonesian vocabulary also end in wan and addition of -wan to some stems is therefore impossible. For instance, the stem Ra has Raningsih, Raningrum, Raningtyas, Rastuti, and Rawati, but not Rawan* as the word means 
'affected, moved, touched' in Indonesian and is mostly used in expressions like rawan gempa, rawan kecelakaan, rawan kejahatan, rawan pangan meaning respectively 'subject to earthquakes, subject to accidents, crime ridden (area), and food shortage' (Stevens and Schmidgall-Tellings 2008: 812-813) and thus would seem unsuitable for a name for a newly born baby. The same holds for Indonesian karya, 'work' which is found in the names Karyaningsih, Karyaningrum, Karyaningtyas, Karyastuti, but rarely Karyawan and Karyawati because they mean male and female employee. The name Warawan exists, but is the name of an orchid and is thus not fit to be used for a boy.

\subsection{2 -NINGSIH, -NINGRUM, -NINGTYAS, -NINGDYAH}

These suffixes consist of two parts, the literary genitive suffix -(n)ing and added sih, rum, tyas, and dyah. They will be referred to as -ningsih, -ningrum, -ningtyas, -ningdyah, but perhaps they should be called -ingsih, -ingrum, -ingtyas, and -ingdyah. They follow the rules of Javanese morphology as with the genitive suffix -ing. This means that the suffix would receive an initial /n/ when attached to a particle ending in a vowel. There is reason for caution here as a choice between -ingsih and -ningsih seems to be open as evidenced by the occurrence of both Nuringsih and Nurningsih. The name Indriassingsih is also a curious exception, as the suffix seems to be -singsih rather than-ningsih.

In our sample, names ending in -ningsih and in -ningrum, are the most frequently found among the quartet -ningsih, -ningrum, -ningtyas, and -ningdyah. Suffix -ningdyah is the least often found among them. Very occasionally, a name that uses one of these suffixes is used by a male. One example is Anas Urbaningrum, the present (2010) chairman of the Democratic Party. We should mention that spelling variation occurs such as -ningroem, -ningtias, -ningtiyas, and -ningdiah, -ningdiyah. The meaning of these suffixes is as follows. -sih means 'love, affection, loving kindness, sympathy, benevolence, favour' (Zoetmulder 1982: 139) and in the eyes of one of my informants refers to gratitude for God's gift. Her reasoning was as follows: -ingsih means Love and as God is love the suffix meaning is as stated above. -rum means 'beauty, loveliness, charm, attractiveness, sweetness, gentleness, fragrance' (Zoetmulder 1982: 1569), -tyas means 'heart', from tyas 'heart, heart as the seat of feelings' (Pigeaud 1938: 609), dyah refers to a 'beautiful lady', from dyah 'young man or woman of noble birth' (Zoetmulder 1982: 450). Although Zoetmulder mentions that the word may also refer to men, in my sample -dyah is only used for women. Thus, Kusumaningsih means 'Flower of the Love of God', Kusumaningrum 'Fragrant Flower', Kusumaningtyas 'Flower of the heart' and Kusumaningdyah 'Lovely Lady like a Flower'. Many people were unable to explain the meaning of their name, however.

\subsection{3-ASTUTI}

-astuti originates from Sanskrit and Old Javanese stuti means: 'song of praise, praise; subject of praise' astuti means 'using (uttering) a stuti' (Zoetmulder 1982:1825) It is usually added to the preceding part without any changes. When 
two variant stems occur such as Adi / Adia (and many more, see below), adding -astuti leads to the same name thus resulting in Adiastuti. In these cases, the real stem is therefore hard to discover and may only be found after interviews with the people who gave the name or with its bearer. Apparently, the first part of the suffix may be replaced. For instance, the name Sri Castuti binti Casmudi. Castuti is no doubt made up of Cas (the first part of the father's name) and -astuti, the name of the mother. Technically the name is thus Cas + tuti. Another enigma is the name Yuwastuti next to Yuastuti. The addition of the approximant / w/ after $Y u$ - may be explained as a pronunciation aid whereas the stem $Y u w$ - may also be a possibility although it has not been found as the stem of any of the other names under discussion. Rarely the suffix -stuti is encountered for males, for instance Yonahes Tristuti Rachmadi Suryosaputra.

\subsection{LINGUISTIC ASPECTS}

Below we will look into some other linguistic aspects of the names in question. We will have a look at the constituting parts of these compounded names and pay particular attention to the first part and see if some order can be made in the large number of names we have found.

We will see that many names are made by using words that derive from various Indonesian and non-Indonesian languages such as Javanese, Indonesian, Arabic, Greek, and Latin and from a variety of personal names stemming from English and other languages. They thus cross the boundaries of languages and transgress linguistic borders, hence the expression crosslanguage and trans-language in the title of this article.

In order to reveal the multilinguistic backgrounds of many of the names, I have indicated below where the first parts of the names derive from so that the reader will instantly become aware that the names are based on particles from different languages that in combination result in something new.

\subsubsection{SANDHI}

In Javanese, sandhi rules require the melting of $/ \mathrm{a} / \mathrm{+} / \mathrm{i} /$ to $/ \mathrm{e} /$ and of $/ \mathrm{a} /$ $+/ \mathrm{u} /$ to $/ \mathrm{o} /$ whereas $/ \mathrm{a} /+/ \mathrm{a} /$ would result in $/ \mathrm{a} /$. These rules rarely apply. Only the following examples where /a/ meets /i/ contracts to /e/ were encountered: Arna + ingsih $=$ Arnengsih, Nurna + ingsih $=$ Nurnengsih, Purna + ingsih $=$ Purnengsih, Purnama + ingsih $=$ Purnamengsih, and Ratna + ingsih $=$ Ratnengsih and Arnawa + ingrum $=$ Arnawengrum and Pratawa + ingrum $=$ Pratawengrum . However, the sample also includes Yunaningsih next to Yunengsih, Pranawaningrum next to Pranawengrum, and Purwaningtyas flanking Purwengtyas and thus, apparently, people may opt to consider the suffix either to be -ingsih,-ingrum, or -ingtyas, resulting in the name with sandhi, or as -ningsih,-ningrum, and-ningtyas, without sandhi. One explanation for this may be that non-Javanese speakers who are unaware of these sandhi rules give these Javanese-sounding names to their children. It may point to the fact that the suffixes indeed start with /n/ and not with the vowel as, otherwise, much more cases of sandhi would be expected. However, the case 
is even more complicated as also Purwa + ningsih $=$ Purwanengsih (next to Purwaningsih), Sekarnengsih exists next to Sekarningsih, and Purwa + ningrum $=$ Purwanengrum have also been found. Perhaps these are exceptions as these are the only examples I have found so far.

Only few examples of sandhi have been found with the addition of the suffix -astuti and thus Andri + -astuti did not lead to Andrestuti* but to Andriastuti. However, Prawiastuti exists next to Prawestuti. Restu + -astuti did not result in Restostuti* but in Restuastuti. When two /a/ meet between the stem and the suffix there are two possibilities, either the /a/ of the suffix is deleted or it is retained. The last happens much more infrequently and in the sample I have only Dewaastuti, Indriaastuti, Novitaastuti and Anaastusi. An / h/ may be added between the stem and the suffix as with Dwihastuti next to Dwiastuti, Trihastuti and Triastuti, Dewihastuti and Dewiastuti also clearly indicating the absence of sandhi.

\subsubsection{NUMBER OF SYLLABLES IN THE FIRST PART OF THE NAMES}

The particles preceding the suffixes can contain various numbers of syllables ranging from one (often consisting of only one consonant) to five of which only three entered our sample Amborowati, Inharicahya, Sunarimahi. Apparently, there is a limit to the length of the first constituent of the names; if the name becomes too long it will become unpleasant and hard to pronounce. At present the total number of syllables of the names is restricted to seven; maximal five plus the two of the suffix used. The bulk of the names consist of three plus two syllables. The following adaptations to the basic words may therefore be understood as to fulfill the requirement of three plus two syllables as the - apparently 'ideal' - length of the names using the principles elucidated in this article.

\subsubsection{ADDED VOWELS AFTER THE FINAL VOWEL OF THE FIRST ELEMENT OF THE COMPOUND}

Two added vowel systems are at work in the construction of the names. Interestingly, both procedures end in the same ending of the first particle.

\subsubsection{1/i $/+\mathrm{a} /$}

When a preceding particle ends in /i/ an /a/ may be added before suffixation. The sample includes, for instance: Hertiningsih, Hertiningrum, Hertiningtyas, Hertiningdyah, Hertiastuti, Hertiwan, and Hertiwati next to Hertianingsih, Hertianingrum, Hertianingtyas Hertianingdyah*, Hertiastuti, Hertiawati, and Hertiawan. ${ }^{16}$ The following pairs were encountered:

Ardi-Ardia, Ari-Aria, Aristi-Aristia, Asri-Asria, Asti-Astia, Astri-Astria, AudiAudia, Budi-Budia, Cari-Caria, Dani-Dania, Desi-Desia, Dwi-Dwia, Fitri-Fitria, Gusti-Gustia, Hani-Hania, Hardi-Hardia, Hari-Haria, Harti-Hartia, Heni-Henia,

16 A *star indicates that the name is theoretically possible, but has not been encountered. 
Herti-Hertia, Isti-Istia, Kerti-Kertia, Kristi-Kristia, Luki-Lukia, Mardi-Mardia, Meli-Melia, Meni-Menia, Murti-Murtia, Musti-Mustia, Nuri-Nuria, Pudji-Pudjia, Seni-Senia, Suri-Suria, Syafri-Syafria, Tri-Tria, Widi-Widia, Yudhi-Yudhia, YudiYudia, Yuli-Yulia, Yuni-Yunia, Yusti-Yustia

\subsubsection{2/a/ $+/ \mathrm{i} /$}

On the other hand, when a particle ends in /a/ an /i/ may be added. Thus we find Faraningsih, Faraningrum, Faraningtyas, Faraningdyah*, Farastuti, Farawati, and Farawan next to Farianingsih*, Farianingrum, Farianingtyas*, Farianingdyah $^{*}$, Fariastuti, Fariawati* and Fariawan*. The following couples were encountered:

Era-Eria, Fara-Faria, Hera-Heria, Herda-Herdia, Inda-India, Indra-Indria, KoraKoria, Kusna-Kusnia, Lisa-Lisia, Lisna-Lisnia, Mida-Midia, Wira-Wiria. ${ }^{17}$

\subsubsection{THE JAVANESE BACKGROUND OF MANY NAMES}

\subsubsection{JAVANESE WORDS AS FIRST PART OF THE NAME}

The most obvious indication that the names derive from Javanese and are used in Java is found when the first part of the words indeed are Javanese words. There are quite a few of them:

Ageng (grand, great), Agung (grand, great), Arda (desirous), Ardi (mountain), Arga (mountain), Arka (sun), Arnawa (sea), Arsa (desire), Arta (money), Arum (fragrant), Asma (name), Asmara (love), Asmoro (love), Asmu (countenance), Asri (pleasant), Asti (elephant), Astra (weapon), Darpa (desirous), Giri (mountain), Baskoro (sun), Lintang (star), etcetera.

\subsubsection{JAVANESE STYLES OF HIGH AND LOW}

Another specific characteristic of Javanese is its various vocabularies of status difference. The low level (ngoko) is found among the names, often flanked by its high level (krama) counterpart, but in surprisingly few instances. For instance: Gede-Ageng, Marga-Mergi, Utama-Utami.

\subsubsection{ALTERNATIVE USE OF JAVANESE AND NON-JAVANESE RULES OF PRONUNCIATION}

The Javanese ethnic background of the names may be glanced from the Javanese pronunciation which rules are evident in the sample. In Javanese, the vocal /a/ is realized as /o/ in open syllables, counting in pairs starting back to front. Thus dana is pronounced dono, nugraha is pronounced nugroho, and narayana is pronounced noroyono. The words used here as the first part of the compounds are indeed Javanese. When they are used in their non-Javanese pronunciation they may be indicative either of non-Javanese background or of an Indonesian cultural/national background while the parent may still

17 The ambiguity of the origins of the names is also evident here. The names starting with Hartia, for instance, can be made of Harta $+i$, or of Harti + a. 
be from a Javanese ethnic background. Thus we find the following pairs: Ekaningsih, Ekaningrum, Ekaningtyas, Ekaningdyah*, Ekastuti*, Ekawati, Ekawan next to Ekoningsih, Ekoningrum, Ekoningtyas, Ekoningdyah*, Ekoastuti, Ekowati, and Ekowan. Consider the following examples from our sample:

Eka-Eko, Asmara-Asmoro, Endra-Endro, Erna-Erno, Jana-Jano, ${ }^{18}$ Kuncara-Kuncoro, Listya-Listyo, Mustika-Mustiko, Nugraha-Nugroho, Panca-Ponco, Pinta-Pinto, Praba-Prabo, Purnama-Purnomo, Purwa-Purwo, Retna-Retno, Rinta-Rinto, Sampurna-Sampurno, Sapta-Sapto, Setia-Setio, Setya-Setyo, Sulistia-Sulistio, Sulistya-Sulistyo, Susila-Susilo, Sutrisna-Sutrisno, Sungkawa-Sungkowo, TejaTejo, Widya-Widyo

\subsubsection{AlTERNATIVE ENDINGS IN / i/ AND /a/}

In Javanese, final / $\mathrm{i}$ / is often used for female and final /a/ for male names. In Indonesian this same phenomenon has been adopted and thus present day Indonesian (but derived from Javanese) putri means a daughter and putra a son, and the Indonesian nouns saudari a female sibling, saudara a male one, siswa 'male pupil' and siswi 'female pupil, mahasiswa 'male student' and mahasiswi 'female student', etcetera. have been constructed in imitation of Javanese. In the sample of the names under discussion, there is also a /i/ /a/ variation in the stems. Dissimilar to what has been said above, this does not indicate gender difference as the names are all used for females. Thus we find Hartaningsih, Hartaningrum, Hartaningtyas, Hartaningdyah*, Hartastuti*, Hartawati, and Hartawan next to Hartiningsih, Hartiningrum, Hartiningtyas, Hartiningdyah, Hartiasturi, Hartiwati, and Hartiwan, etcetera. Consider the following pairs:

Arda-Ardi, Arma-Armi, Asma-Asmi, Asta-Asti, Astra-Astri, Buda-Budi, DanaDani, Darma-Darmi, Darpa-Darpi, Darsa-Darsi, Dewa-Dewi, Erna-Erni, HartaHarti, Jula-Juli, Karna-Karni, Karta-Karti, Kendra-Kendri, Lasma-Lasmi, Lena-Leni, Lesma-Lesmi, Marga-Margi, Marta-Marti, Mela-Meli, Mera-Meri, Merga-Mergi, Muda-Mudi, Muhara-Muhari, Murja-Murji, Murta-Murti, Nira-Niri, Parta-Parti, Patma-Patmi, Pudja-Pudji, Puja-Puji, Pura-Puri, Putra-Putri, Ramada-Ramadi, Ramda-Ramdi, Ruma-Rumi, Rusma-Rusmi, Sara-Sari, Suharta-Suharti, Sura-Suri, Warda-Wardi, Warta-Warti, Werda-Werdi, Wida-Widi, Yoga-Yogi, Yuda-Yudi, Yuna-Yuni, and Yusma-Yusmi,

\section{PROPER NAMES PLUS SUFFIX ${ }^{19}$}

Quite a few names were formed on the basis of an existing proper male or female name such as Cesar, Ely, Emilya, Erika, Gloria, Helga, Herma, Hilda, Ida, Ina, Johan, Julia, Kristina, Linda, Lisa, Luciana, Mahendra, Mahindra, Maria, Melda, Natali, Ratna, Silvia, Sri, Susan, Synthia, Tani, Tina, Tuti, Vera, Wanda, and

18 As with the couple Praba-Prabo, the /a/ - /o/ there is only partly /a/ - /o/ pronunciation as the rules of Javanese pronunciation would have led to Praba-Probo* and JanaJono*.

19 In the instances mentioned below, not all seven names of the septets have been encountered but at least one of them has entered the sample. 
Yeni. Also here not all the seven suffixes are represented for every name. The one mostly found is Ratna which has all seven: Ratnaningsih, Ratnaningrum, Ratnaningtyas, Ratnaningdyah, Ratnastuti, Ratnawati and Ratnawan, while others, such as Cesar has only been found in combination with-ningrum: Cesarningrum. Included here are names made on the basis of the proper name of a national hero or president as mentioned above.

\subsection{RELIGIOUSLY INSPIRED NAMES}

The suffixes may be attached to names indicative of various religious strands, Muslim, Christian, Buddhist, and Hindu.

\subsection{MUSLIM NAMES}

The following Muslim and Islamic names have been encountered: Achsa, Aishah, Aisya, Aisyah, Ali, Amin, Farhan, Fatima, Fatwa, Fitri, Fitria, Isa, Isra, Miraj, Noor, Nur, Nurrohma, Rachma, Rahma, Rakhma, Ridha, Ridho, Ridla, Rochma, Rochmya, Rohma, Rokhma, Rosdiana, Rufina, Takwa, Taqwa, Umar, and Wahyu. Names based on Rahma and Rohma (regardless of their spelling) have been encountered most: Rahmaningsih, Rahmaningrum, Rahmaningtyas, Rahmaningdyah, Rahmastuti, Rahmawati, and Rahmawan, and the same set starting with Rohma.

\subsection{CHRISTIAN NAMES}

Only three Christian names have been found as the first part of the compounds, Ana, Anna and Maria of which all seven names are found with the exception of Annaningdyah*.

\subsection{BUDDHIST AND HINDU NAMES}

The following Buddhist and Hindu and Hindu-inspired names including characters from the Mahabharata were found: Astina, Brama, Buda, Endra, Endro, Indra, Karna, Kresna, Krisna, Kumara, Laksmi, Rama, Ratih, Sinta, Shinta, Soma, Sri, Supraba, Weda, and Wisnu.

\section{NAMES BASED ON NAMES OF DAYS, MONTHS, AND OTHER TIME INDICATORS ${ }^{20}$}

Very popular are combinations with an indication of a month of the Gregorian or Muslim Calendar or another indication of time such as the day of the week. Usually not the whole name of the month is used, but part thereof or a name closely indicative of the name of the month.

20 The origin of the names and the nouns to be discussed will be provided to indicate the trans-language aspect of the names. Ar. is indicative of Arabic, Gr. of Greek, Ind. of Indonesian, Jv. of Javanese, Jap. for Japanese, and Lat. for Latin. 


\subsection{MONTHS IN THE GREGORIAN CALENDAR}

The following stems were encountered: January: Januari; February: Febri, Pebria; April: Apri, Apria, Aprili; May: Mei, Meiti, Meity; June: Juni, Junia, Juniarti, Yuni, Yunia; July: Juli, Julia, Yuli, Yulia; August: Agusta, Agusti, Agustia, Agustina; September: Septi, Septia, Septya; October: Octa, Okta; November: Novi, Novia, Novita; December: Desi, Desia.

\subsection{MONTHS IN THE MUSLIM CALENDAR}

The following (all Arabic) stems were found: Muharram, Ramdana, Sawal, Syafar, Syawal.

\subsection{DAYS OF THE WEEK}

The following days were found: Ahad (Ar. Sunday), Kamis (Ind. Thursday), Minggu (Ind. Sunday), Rabu (Ind. Wednesday), Sabtu (Ind. Saturday), Selasa (Ind. Tuesday), Legi (Jv. second day of the Javanese five-day week), Pon (Jv. forth day of the Javanese five-day week), Sukra (Jv. Friday), Wage (Jv. fifth day of the Javanese five-day week).

\section{VARIOUS WORD CLASSES AS THE FIRST PART OF THE COMPOUND 5.1 NOUNS}

Because of their great variety, it is impossible to go into all aspects of the kinds of nouns added to the suffixes in our sample. A variation of nouns may be used for a name. They may easily be grouped on the basis of the semantic group they belong to.

\subsubsection{PRECIOUS METALS AND GEMS}

Berlian (Ind. brilliant), Intan (Ind. diamond), Kencana (Jv. gold), Komala (Ind. benzoic), Kumala (Jv./Ind. benzoic), Mas (Ind. gold), Mirah (Jv. ruby), Mustika (Jv./Ind. bezoar) Permata (Ind. gem), Ratna (Ind. agate), Retna (Jv. agate), Retno (Jv. agate). ${ }^{21}$

\subsubsection{FLOWERS}

Bunga (Ind. flower), Dhalia (Ind. dahlia), Kesuma (Jv. flower), Kusuma (Jv. flower), Mawar (Ind. rose), Melati (Ind. jasmine), Padma (Jv. lotus), Patma (Jv. lotus), Puspa (Jv. flower), Sakura (Jap. sakura), and Sekar (Jv. flower).

\subsubsection{HEAVENLY BODIES}

Bulan (Ind. moon), Aditya (Jv. sun), Candra (Jv. moon), Chandra (Jv. moon), Kartika (jv. star), Komar (Ar. moon), Lintang (Jv. star), Luna (Lat. sun), Raditya (Jv. sun), Ratih (Jv. moon), Rawi (Jv. sun), Surya (Jv. sun), Tjandra (Jv. moon), and Wulan (Jv. moon).

21 The words Ratna, Retna and Retno are also used for proper name in itself and therefore has already been mentioned above. 


\subsubsection{FAMILY MEMBERS}

Adi (Jv. younger sibling), Ari (Jv. younger sibling), Cucu (Ind. grandchild), Putra (Ind./Jv. son), Putri (Ind./Jv. daughter), Putro (Jv. son), Siwi (Jv. child, son), Suta (Jv. child, son), Tanaya (Jv. child, son), Tanoyo (Jv. child, son) Umi (Ar. mother).

\subsection{NUMERALS AND OTHER INDICATIONS OF SEQUENCE}

Names starting with a numeral or with the indication of a letter of the Greek alphabet, all indicating the ranking order within the group of siblings:

\subsubsection{NUMERALS}

Asta (Jv. eight), Dwi (Jv. two), Eka (Jv. one), Eko (Jv. one), Esa (Ind. one), Panca (Jv. five), Lima (Ind. five), Pertama (Ind. first), Penta (Gr. five), Pitu (Jv. seven), Ponco (Jv. five), Sapta (Jv. seven), Sapto (Jv. seven), Satu (Ind. one), Tetra (Gr. four), Tiga (Ind. three), Tri (Jv. three), Wolu (Jv. eight).

\subsubsection{GREEK LETTERS}

Only three Greek letters have been found: Alfa, Beta, Gama.

\subsubsection{ARABIC LETTERS}

The only Arabic letter that entered the sample is Alif.

\subsection{ADJECTIVES}

Usually adjectives are used that carry a propitious or otherwise nice and fortunate meaning. Consider the following examples:

Abadi (Ind. everlasting), Adi (Jv. splendid, glorious), Ageng (Jv. grand), Agung (Jv. grand), Aneka (Ind. multifarious), Arum (Jv. fragrant, soft and sweet), Ayu (Jv. beautiful [of a lady]), Jaya (Ind./Jv. victorious), Sampurna (Ind. perfect), Sampurno (Jv. perfect), Setia (Ind. loyal, faithful), Setio (Jv. loyal, faithful), Setyo (Jv. loyal, faithful), and Wijaya (Ind. victorious).

\section{SOME HISTORICAL, CULTURAL, AND SOCIAL BACKGROUND}

The historical and cultural background of the suffixes is explained by suffix. Please note that the information is fragmented and I have not been able to find equal amounts of information of each individual suffix.

\section{1 - WATI}

Within our sample, -wati is by far the most productive suffix for making female names and is found all over the archipelago. The -wati suffix is encountered in a variety of spellings such as -wati, -wathi, -watie, -waty, and -wathy. Incidentally, Yanwati is the only example of a male name ending in -wati in my sample. 
6.1.1 -WATI IN THE WAYANG (SHADOW PLAY) REPERTOIRE AND JAVANESE LITERATURE

-wati is a suffix particle that stems from India and, somewhere in the ninth or tenth century, has entered the Indonesian archipelago probably with the introduction of the Sanskrit epic Mahäbhärata in which this particle is often used for the names of female characters, but also for countries and, very rarely, for men. Early on, the epic was popularized in the Javanese context in Old-Javanese prose (parwa) and poetic adaptations (kakawin) but has probably become much more popular and well-known through the wayang (Javanese shadow- and other puppet plays) and has entered the wider Javanese world probably first through this medium although this is easier said than proved. ${ }^{22}$ My sample of names indicates that quite a few wayang names are in general use today in the real world, especially when they have a certain auspicious meaning. For instance, Setyawati (faithful girl), Susilowati (ethical woman), while the name of the Goddess of Science and Wisdom; Saraswati is also frequently given to a baby girl, especially in Bali.

Some rare examples of male names ending in -wati include Prabu Mugiwati from West Java ${ }^{23}$ and Sasanawati, the King of Cempa. ${ }^{24}$ The epithet Anyakrawati is given to the highest God, usually Indra or someone equated with his rank, and is found in many stories not only in Java but also in Javanese stories elsewhere in the archipelago but unknown in Java like the Puspakrama from Lombok where it is used as a verb, 'to rule the whole world' (Van der Meij 2002: 58). The name is also known in Javanese history as the King of Mataram, Hanyakrawati (Sedo ing Krapyak), who ruled from 1601 to 1613 (Poespaningrat 2008: 25).

Apart from the Mahäbhārata, names ending in -wati are also found in other literary works. For example, in the Serrat Gatholoco we find the name Perjitawati (Ricklefs 2007: 190), which is also mentioned in the Sĕrat Dĕrmogandhul (Ricklefs 2007: 196). In the Javanese text, Kabarsundari from Lombok the particle is used for the name of Queen Nayawati, and for Gandawati, the daughter of a spirit (jin) (See Kabarsundari 2002). The suffix -wati is also used for yet quite another kind of phenomenon, kakawin metres. Kakawin are poems in Old Javanese that use Sanskrit or Sanskrit-derived metres. The following names for metres

22 This following names were found in Soekatno n.d., Purwadi 2007, Sucipto 2010, Poespaningrat 2008, and Lucas 1973. It has no pretention of being exhaustive for the entire wayang repertoire, however.Among the wayang repertoire, the following female names ending in -wati were encountered: Agnyanawati, Banowati, Citrawati, Dursilawati, Erawati. Gandawati, Gendrawati, Herawati, Jembawati, Kemudawati, Kencanawati, Kumudawati, Lesmanawati, Mindakawati, Nalawati, Nilawati, Pramuwati, Pregiwati, Pujawati, Purwati, Sarasawati, Setyawati, Srengganawati, Srenggeniwati, Suryawati, Susilowati Janakawati (http:/ / wayang.wordpress.com/ 2010/03/10/ antasena-rabi-2/, accessed 16-9-2010), and Partawati (http://www.tembi.org/ wayang/20100827-Babad_Wanamarta. htm, accessed 16-9-2010). There are doubtless many other wayang ladies whose names end in -wati I have not yet found. Kresna's famous kingdom in the wayang world is called Dwarawati, also called Pancawati (See illustration 160 in Schat 2007), Darawati, Durawati and Drawati (Lucas 1973: 330).

23 Manuscript VdM J25, p. 19.

24 Manuscript VdM J25, p. 35. 
were found: Rukmawatì, Lakșmìwatì, Citrawatì, Amarawatì, Prabhāwatì, Erawatì, Wegawatī (Zoetmulder 1985: 563-580) whereas Rubinstein also mentions Malāwati (Rubinstein 2000: 246). The names ending in -watì in Old Javanese literature based on the Mahäbhārata, of course, are those found in their Sanskrit original. This is also true for the many kakawin based on this text. To name but some examples from kakawin not based on these texts the following may suffice. Only one name ending in -watī is found in the Nägarakrtägama. It concerns Parama Bagawati and is found in canto 2 (Slamet Mulyana 2006: 338, 427). In the Kakawin Sutasoma we find the names Candrawatì, Marmawatī, Puspawatì,

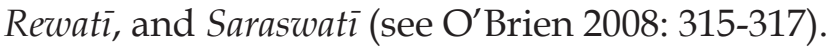

Above we have restricted ourselves to a short investigation into names ending in -wati in Javanese literature and history. We should bear in mind that we also encounter many of these names in other literatures in the Archipelago, especially in Malay, particularly in texts that are also adaptations of the Mahābhārata.

\subsection{2 - WATI IN JAVANESE HISTORY AND SOCIETY}

In Javanese history names ending in -wati are also often encountered. By lack of information, most names were found in the highest social circles of the palace surroundings of Central Java. ${ }^{25}$ Many of the consorts, daughters, and granddaughters of the kings of Java carry names ending in -wati. For instance Ontawati, Pergiwati, the daughters of Paku Buwono X (Ramelan n.d.: 165-166), whose granddaughters include Saraswati, Kusamarawati, Kadarwati, Handriyawati, Trisetyawati, Kusniawati, Kusumawati, Rachmawati, Kuspartinawati, Antawati, and Mirawati (Ramelan n.d.: 188, 190-191, 200-201, 205-208).

Diponegoro, whose mother was named Mangkarawati, was married to Raden Ayu Renadiwati (Carey 2008: 766), a name not found in the manuscript used above. We see that the names ending in -wati at the royal Central Javanese courts were ubiquitous and present since the founding of the Javanese kingdoms.

Also in Surakarta, names ending in -wati were in use in the royal family of Susuhunan Paku Buwono X (1866-1939) (Ramelan n.d.: 2-4), as evidenced by the following names: Rahwati, Prabawati, Setyawati, Kadarwati, Setyowati, Saraswati, Kusamarawati, Handriyawati, Trisetyawati, Kusniawati, Kusumawati, Rachmawati, Mulistyawati, Kuspartinawati, and Mirawati (Ramelan n.d.: 187-191, 198, 200-201, 205-206, 208).

The genealogy of the Kingdoms of Pajajaran, Banten and Cirebon contains the name Pakungwati (Poespaningrat 2008: 17), the families of the Walisongo

25 A manuscript containing the genealogies of the royal house of Yogyakarta mentions the following female names Sarngwati, Inawati, Dreswati, Retnawati, Nilawati, Rakathawati, Gondawati, Padmawati, Citrawati, Pancawati, Mundhingkawati, Tejawati, Idawati, Winakawati, Mangkarawati, Kalpikawati, Surtikawati, Manukmawati, Lesmanawati, Puspitawati, Patmawati, Mulyawati, Condrawati, Murcitawati, Widawati, Prenukmawati, Sokawati, Teliwati, Tinawati, Pujawati, Kenakawati, and Sedhawati (Manuscript VdM J35). Please note that the information mentioned in books on the Central Javanese palaces and that found in manuscripts are mutually additional. 
(holy Muslim saints of Java) include the names Dwarawati and Candrawati which thus go back to pre-1400 AD (Poespaningrat 2008: 25).

\subsection{3 -WATI USED FOR NAMES OF NON-HUMAN CHARACTERS}

Names ending in -wati are also not restricted to human females. In the domain of spirits, names ending in -wati are encountered such as Rawati, ${ }^{26}$ the nymph Rekathawati the wife of Sang Hyang Tunggal ${ }^{27}$ and Gandawati as mentioned above in the Kabarsundari. Apart from Saraswati, the world of the goddesses is moreover populated by Sarwati, the wife of Nurrasa, Ratnawati, a genie princess who was married to the crab Rekatatama whereas one of Ismaya (Semar)'s daughters was called Sarmanawati (Poespaningrat 2008: 4).

\subsection{4 -WATI IN TOPONYMS}

-wati is also used in toponyms such as Sokawati, which is the name of a kingdom mentioned in a manuscript on the genealogical lines of the royal house of Yogyakarta. ${ }^{28}$ Sukawati is also the name of a small town in Bali and Sokawati that of a small town in Java while Pancawati is the name of a village in West Java. Because Sukawati is also the seat of one of the lesser princedoms in Bali, it has entered the domain of personal names as well and the local prince is usually known as Cokorda Sukawati.

\section{2 -WAN}

The history of the suffix -wan is not so easy to follow. It is also derived from Sanskrit as a suffix indicating a male individual. In the wayang world, there are names like Irawan (Sucipto 2010: 7) and Ngurawan (Lucas 1973: 333). Irawan is also the name of one of the sons of Paku Buwono X of Surakarta (Ramelan n.d.: 166) while his grandsons include Setiawan, Rindriawan, Windrayawan, and Widiawan (Ramelan n.d.: 178, 185, 199, 208). At present names ending in -wan are ubiquitous and in the sample almost equal the number of names ending in -wati.

The male suffix -wan is so well known that it has been afforded the role of indicating a male person of a certain capacity or having a specific occupation. For the female counterparts, the same words but ending in -wati may be used. The Kamus Besar Bahasa Indonesia thus contains many words ending in -wan and -wati denoting persons who have a specific job or are engaged in certain activities and interests. Many of them have also entered the Comprehensive Indonesian-English Dictionary by Alan M. Stevens and A. Ed. Schmidgall-Telings. For instance, acarawan-acarawati ${ }^{*}$, agamawan-agamawati, aksarawan-aksarawati, algojo-algojowati, biarawan-biarawati, and hundreds more. Interestingly, in the dictionary there is no one to one correspondence between these gender related words. Often the male -wan variant is included but not

$26 \quad$ Manuscript VdM J25, p. 12.

27 Manuscript VdM J25, p. 40.

28 Manuscript VdM J25, p. 32. 
the corresponding female -wati, which is a strange and unnecessary gender bias unworthy of this dictionary and this bias is nowhere explained or justified. Sometimes the absence of the male variant is understandable. An algojo is an executioner and a male variant algojowan* is unnecessary hence I only found algojowati for female executioner. A pramuka is a Boy Scout and pramukawan* is therefore also superfluous. Pramukawati is listed, however. Whether or not many these words remain inventions of the Indonesian Language Center, Pusat Bahasa, or are really used in everyday language remains a question though, as no research has been done to investigate this.

\section{3 -NINGSIH, -NINGRUM, -NINGTYAS, -NINGDYAH}

The only example of a name ending in -ningsih in the wayang theatre I have been able to find is Wrediningsih (Soetkatno, [n.d.] 184) whereas one of the major female characters in Javanese mask dances, Ragil Kuning is also known under the name Andaningsih (Lucas 1973: 329). The only name ending in -ningrum I found is Prabu Ajijaya Diningrum, King of Jongparang. ${ }^{29}$

Names carrying these suffixes are also known from a Javanese cultural and historical background: that of the wives of lesser rank (garwa ampeyan, selir) of the four princes of Central Java, the Sultan and Paku Alam in Yogyakarta, and the Susuhunan and Mangkunegoro in Solo, and their daughters. Names I was able to find in this connection include Suwenaningsih, Semaraningsih, Pujaningsih, wives of Sultan Hamengkubuwono II (1750-1828) (Carey 2008: 760) of Yogyakarta: Kumunaningsih, Mulyaningsih, Sesmitaningsih, Puspitaningsih, Dewaningrum, and Adiningdyah of Sultan Hamengkubuwono III (1769-1814) (Carey 2008: 760); Padmaningsih, Dewaningrum, Retnaningrum, and Murcitaningrum of Sultan Hamengkubuwono IV (1804-1822) (Carey 2008: 760); Murtiningrum, wife of Hamengkubuwono V (1820-1855) (Dwiyanto 2009: 249); Puspitaningrum, Murtiningrum, Retnoningrum, and Retnaningdyah, wives of Hamengkubuwono VI ${ }^{30}$ (1821-1877) (Dwiyanto 2009: 305), Retnoningsih and Retnoningdyah of Sultan Hamengkubuwono VII (1839-1921) (Dwiyanto 2009: 347), ${ }^{31}$ and Windyaningrum (Poespaningrat 2008: 110), the second wife of Hamengkubuwono IX (1912-1988) (Dwiyanto 2009: 489). Hamengkubuwono VIII (1880-1939) (Dwiyanto 2009: 443) had four selirs: Moertiningdyah,

$29 \quad$ Name and illustration of this puppet in Lysloff 2009: 527.

30 Manuscript VdM J35. The names of these selirs were often made by repetition of a certain particle. For instance, the names of many of the selirs of Hamengkubuwono VII started with Retno: Retnoningdyah, Retnoningsih, Retnohadi, Retnosangdyah, Retnohadiwati, Retnojuwito, Retnomurcito, Retnopurnomo, Retnojumanten, Retnowinardi, Retnomandoyo, Retnorenggohasmoro, Retnosocohasmoro, and Retnoliringhasmoro, while one ended in Retno: Pujoretno (Ngeksi Ganda 11-20). 26 out of 30 names of the selirs of Pakubuwono X ended in -rukmi (see Ramelan n.d.: 164-165).

31 Manuscript VdM J35. Official or semi-official books on the palaces and princes of Central Java (Yogyakarta and Surakarta) often omit the names of the lesser wives and they only feature when they are mothers of the rulers' children. It is therefore sometimes necessary to resort to manuscripts in order to find out whether these names were used at certain times. See also Poespaningrat 2008: 243. 
Poedjaningdyah, Poespitaningdyah, Hadiningdyah (Ngèksi Ganda 25). That the names ending in the suffixes under discussion were not limited to the wives of the ruling princes but also to their family members is evidenced by Retnaningrum and Retnaningsih, who were among Diponegoro's wives (Carey 2008: 768).

Staying in Yogyakarta, Paku Alam II was married to Resminingdyah (Poespaningrat 2008: 142); one of the lesser wives of Paku Alam IV (18641878) (Dwiyanto 2009: v) was called Rengganingsih (Dwiyanto 2009: 40). Paku Alam VIII married Purnomoningrum and Retnoningrum (Poespaningrat 2008: 142), while the consort of the present Paku Alam IX is called Purnamaningrum (Dwiyanto 2009: 97).

In Surakarta, the social status of names ending in these suffixes had apparently gone through some changes under the rule of Paku Buwono X. The names of his granddaughters include: Ayuningtyas, Putrihestiningtyas, Hestiningtyas, Winarsiningsih, Winasriningdyah, Winasiningrum, Sisdjatiningrum, Puspaningrum, Puspaningsih, and Kusumaningtyas (Ramelan n.d.: 192, 196, 198, 206-207). Five unofficial wives of Susuhunan XII (1925-2004) of Surakarta were: Pradapaningrum, Mandayaningrum, Kusumaningrum, Retnadiningrum, and Pujaningrum (Suara Merdeka daily, 12 June 2004).

These names were also present among the wives of lesser princes and nobles and in the nineteenth century. For instance, the Regent of Banyumas had three selirs, among them Rengganingsih and Pujaningrum (Dwiyanto 2009: 40).

\section{$6.4-A S T U T I$}

Only few wayang characters carry names ending in -astuti, for instance Durmastuti while also Hastuti is used. Like the names ending in the other suffixes, it is also found among the names used for princesses in the palace of Yogyakarta, e.g. Sitiwidiyastuti, the 29th child of Hamengkubuwono VIII. Pakubuwono X had a wife named Ruwiastuti (Ramelan n.d.: 169). The only reference so far of a goddess with an -astuti name is Darmastuti, the daughter of Sang Hyang Tunggal and Dewi Darmani.

As with the names discussed above, in Solo the social status of names ending in these suffixes had apparently also gone through some changes under the rule of Paku Buwono X (1866-1939) (Ramelan n.d.: 2-4). The names of his granddaughters include: Sri Astuti, Murtiastuti, Pujastuti, Widiastuti, Mahindrastuti, and Andriastuti (Ramelan n.d.: 193-194, 198, 201-202, 207). The suffix is also rarely found spelled as -astuty, -astutie, and -astoeti.

\section{CONCLUSION}

In Indonesia, making new names is an everyday phenomenon. People can give their new-born babies any name they like but usually names are given that will help the child through life. Apart from that, names should also sound nice. Names may be provided by parents, but also by others like other family members. Many names are made on the basis of productive morphological processes as has been shown above. More morphological processes are at 
work to create female names than to create male names.

Adding the suffix -wati is the most popular way to make new female names. Its number is almost matched by its male counterpart -wan. In the case of names ending in-ningsih,-ningrum, -ningtyas, -ningdyah, and-astuti, there seems to have been a kind of liberation process of name giving practices in Indonesia. The construction of names based on these suffixes, which were more or less constricted to usage in the palace surroundings of Central Java have been "liberated" from their cultural confinement and are now free for anyone's usage. Based on the staggering number of names based on these principles, they can seemingly be compiled at random on the basis of a variety of word classes of which proper names, some nouns, numerals and adjectives have been shown above.

Another obvious observation is that the names given to girls far outshine those of boys when looked at for auspicity and beauty of sound; the only productive procedure that is used is that of the affixation of - wan. The names are moreover often used in combination for extra impact and simply because they sound even more pleasurable.

The trend in the use of names ending in the suffixes in this article seems moreover to be free of religious constraints and is also otherwise not restricted. The random sample used for this article reveals that the people who carry the names discussed above originate from all levels of society and are employed in all sorts of jobs ranging from university professor to soothsayer healer from the North Coast of Java.

Although, based on the sample, names ending in -ningdyah seem to be least popular and those ending in-wati are most often found, followed by -ningsih, and -ningrum. This is not to say that this may not change any moment, as the trend to extra individuality is also apparent in name giving practices. The providers of the names are obviously acutely aware that a name they would like to give is not actually an existing word in the Indonesian language. When this is found to be so, they are usually excluded from this "system". Apart from the examples above we may mention melawan*, which might be made on the basis of mela + wan (Melaningsih and Melawati exist), but since the word melawan means 'to oppose' in Modern Indonesian it is, of course, not used as proper name. The same holds for seriawan* (seria + wan) which, meaning 'sprue' is unfit for a proper name (whereas Serianingsih, Serianingrum, Seriastuti and Seriawati do exist) and hewan* (he + wan) which means 'animal' (whereas Heningsih, Heningrum, Heningtyas, Heastuti, and Hewati are in use), is also not the most elegant name to give to a newborn baby.

The names ending in -wati are ubiquitous and are given to baby girls all over the archipelago. Names ending in -ningsih, -ningrum, -ningtyas, and -ningdyah originate from Java but are leaving their Javanese surroundings and are nowadays given to baby girls in Bali and other places in the archipelago. This means that there is a certain movement away from ethnic-bound proper names in favour of names that are Indonesia-bound and ethnic free.

This leaves us with the problem of popularity. Glancing through newspapers 
and any other printed works might lead us to think that for girls the name Rahmawati is extremely popular whereas the name Kusumaningsih and Kusumaningrum are also very frequently found. The name Gunawan is old and given to an overwhelming number of baby boys. Another problem is of course the extreme rareness of certain names. Saharawati has been found only once and the lady carrying the name told me shyly that she would rather just be called Sahara and to leave the -wati part as she thought it did not sound nice.

The fact that in the making of the names the rules of sandhi often do not apply may be taken as an indication that these names are no longer considered exclusively Javanese but have entered the domain of Indonesian names.

\section{REFERENCES}

\section{MANUSCRIPTS}

Ms VdM J25. Punika serat pethikan sajarah wiwit saking Gusti Kangjeng Nabi Adam Safiyullah.

Ms VdM J35. Primbon plus genealogy of the princes and princesses of Yogyakarta.

\section{PUBLISHED SOURCES}

Angst, Walter. 2007. Wayang Indonesia; Die phantastische Welt des indonesischen Figurentheaters/The fantastic world of Indonesian puppet theatre. Konstanz: Verlag Friedr. Stadler.

[Bramono]. [1940]. Sinoewoen Ngèksi Ganda. Ngajogjokarta Joeningrat.

Carey, Peter. 2008. The power of prophecy; Prince Dipanagara and the end of an old order in Java, 1785-1855. Leiden: KITLV Press.

Cika, I Wayan. 1990. "Nama-nama orang Bali: suatu catatan kecil"; laporan penelitian oleh I Wayan Cika, I Nyoman Astika and I Made Suida. Denpasar: Fakultas Sastra, Universitas Udayana.

Dwiyanto, Djoko. [2009]. Puro Pakualaman; Sejarah, kontribusi dan nilai kejuangannya. Yogyakarta: Paradigma Indonesia.

Eechoud, J.P.K. van. 1962. Etnografie van de Kaowerawédj (Centraal NieuwGuinea). 's-Gravenhage: Nijhoff. [Verhandelingen KITLV 37.]

Hinzler, H.I.R. 1988. "On Balinese name-giving rituals", in: Papers from the III European Colloquium on Malay and Indonesian Studies (Naples, 2-4 June, 1981), pp. 121-146. Napoli: Instituto Universitario Orientale.

Hylkema, S. o.f.m. 1974. Mannen in het draagnet: Mens- en wereldbeeld van de Nalum (Sterrengebergte). 's-Gravenhage: Nijhoff . [Verhandelingen KITLV 67.]

Kabarsundari. 2002. Alihaksara dan terjemahan naskah lontar pesasakan Kabarsundari. Mataram: Pemerintah Propinsi Nusa Tenggara Barat, Dinas Kebudayaan dan Pariwisata, Taman Budaya Propinsi Nusa Tenggara Barat.

Lucas, Heinz. 1973. Java-Masken; Der Tanz aufeinem Bein. Kassel: Erich RöthVerlag. [Die grosse Maskenkunde 4.] 
Lysloff, René T.A. 2009. Srikandhi dances lènggèr; A performance of music and shadow theater in Central Java. Leiden: KITLV Press.

Mahendra Sucipto. 2010. Ensiklopedia tokoh-tokoh wayang dan silsilahnya. Yogyakarta: Narasi.

Meij, Th.C. van der. 2002. Puspakrema; A Javanese romance from Lombok. Leiden: Research School of Asian, African, and Amerindian Studies, Universiteit Leiden.

O'Brien, Kate. 2008. Sutasoma; The ancient tale of a Buddha-Prince from 14th century Java. Bangkok: Orchid Press.

Pigeaud, Th. 1938. Javaans-Nederlands handwoordenboek. Groningen-Batavia: Wolters.

Poespaningrat, Pranoedjoe. 2008. Kisah para leluhur dan yang diluhurkan dari Mataram Kuno sampai Mataram Baru. N.p.: Kedaulatan Rakyat.

Purwadi. 2007. Pelestarian budaya Jawa; Mengenal tokoh wayang purwa dan keterangannya. Sukoharjo-Surakarta: Cendrawasih.

Ramelan, KRT. Kastoyo. n.d. Sinuhun Paku Buwono X; Pejuang dari Surakarta Hadiningrat. Bandung: Jeihan Institute.

Ricklefs, M.C. 2007. Polarising Javanese Society; Islamic and other visions (c. 18301930). Leiden: KITLV Press.

Rubinstein, Raechelle. 2000. Beyond the realm of the senses; The Balinese ritual of kekawin composition. Leiden: KITLV Press.

Slamet Mulyana. 2006. Tafsir Sejarah Nagara Kretagama. Yogyakarta: LKiS.

Soekanto. n.d. Wayang kulit purwa; Klasifikasi jenis dan sejarah. Semarang: Aneka Ilmu.

Stevens, Alan M., and A. Ed. Schmidgall-Tellings. 2008. Kamus Lengkap Indonesia-Inggris; A comprehensive Indonesian-English dictionary. Bandung: Mizan.

Tambayong, Yapi. 2007. Kamus bahasa dan budaya Manado. Jakarta: Gramedia Pustaka Utama.

Uhlenbeck, E.M. 1978. Studies in Javanese morphology. Den Haag: Nijhoff. [KITLV Translations Series 19.]

Uhlenbeck, E.M. 1982. Kajian morfologi bahasa Jawa. Jakarta: Djambatan. [Seri ILDEP 4.]

Zoetmulder, P.J. 1982. Old-Javanese-English dictionary. 's-Gravenhage: Nijhoff.

Zoetmulder, P.J. 1985. Kalangwan; Sastra Jawa Kuno selayang pandang. Jakarta: Djambatan. [Seri ILDEP 9.] 